Chapman University

Chapman University Digital Commons

Food Science Faculty Articles and Research

Food Science

3-2-2016

\title{
Use of the Mitochondrial Control Region as a Potential DNA Mini-Barcoding Target for the Identification of Canned Tuna Species
}

Jacquelyn K. Mitchell

Chapman University

Rosalee S. Hellberg

Chapman University, hellberg@chapman.edu

Follow this and additional works at: http://digitalcommons.chapman.edu/food_science_articles

Part of the Aquaculture and Fisheries Commons, Food Biotechnology Commons, Food Microbiology Commons, Meat Science Commons, Other Animal Sciences Commons, and the Other Food Science Commons

\section{Recommended Citation}

Mitchell, J.K., Hellberg, R.S., 2016. Use of the mitochondrial control region as a potential DNA mini-barcoding target for the identification of canned tuna species. Food Anal. Methods (2016) 9: 2711. doi:10.1007/s12161-016-0460-3

This Article is brought to you for free and open access by the Food Science at Chapman University Digital Commons. It has been accepted for inclusion in Food Science Faculty Articles and Research by an authorized administrator of Chapman University Digital Commons. For more information, please contact laughtin@chapman.edu. 


\section{Use of the Mitochondrial Control Region as a Potential DNA Mini- Barcoding Target for the Identification of Canned Tuna Species}

\section{Comments}

NOTICE: this is the author's version of a work that was accepted for publication in Food Analytical Methods. Changes resulting from the publishing process, such as peer review, editing, corrections, structural formatting, and other quality control mechanisms may not be reflected in this document. Changes may have been made to this work since it was submitted for publication. A definitive version was published in Food Analytical Methods, volume 9, issue 10, in 2016. DOI: 10.1007/s12161-016-0460-3

The Creative Commons license below applies only to this version of the article.

\section{Creative Commons License}

\section{(c) 1 (1) 90}

This work is licensed under a Creative Commons Attribution-Noncommercial-No Derivative Works 4.0 License.

\section{Copyright}

Elsevier 
3

4 Jacquelyn K. Mitchell, Rosalee S. Hellberg*

5

6 Chapman University, Schmid College of Science and Technology, Food Science and Nutrition, One

7 University Drive, Orange, CA 92866

8

$9 \quad *$ Corresponding Author:

10 Rosalee S. Hellberg, Ph.D

11 Chapman University

12 Ph: 714-628-2811

13 Fax: 714-289-2041

14 Email: hellberg@,chapman.edu

15 


\section{Abstract}

In this study, a DNA mini-barcoding methodology was developed for the differentiation of species commonly found in canned tuna. Primers were designed to target a 236-base pair (bp) fragment of the mitochondrial control region (CR) and a 179-bp fragment of the first internal transcribed spacer region (ITS1). Phylogenetic analysis revealed the ability to differentiate 13 tuna species on the basis of the CR mini-

21 barcode, except in a few cases of species introgression. Supplementary use of ITS1 allowed for

22 differentiation of introgressed Atlantic bluefin tuna (Thunnus thynnus) and albacore tuna (Thunnus alalunga), while differentiation of introgressed Atlantic bluefin tuna and Pacific bluefin tuna (Thunnus orientalis) requires a longer stretch of the $\mathrm{CR}$. After primer design, a market sample of 53 commercially canned tuna products was collected for testing. This mini-barcoding system was able to successfully identify species in 23 of the products, including albacore tuna, yellowfin tuna (Thunnus albacares), and skipjack tuna (Katsuwonus pelamis). One instance of mislabeling was detected, in which striped bonito (Sarda orientalis) was identified in a product labeled as tongol tuna (Thunnus tonggol). PCR amplification and sequencing was unsuccessful in a number of products, likely due to factors such as the presence of PCR inhibitors and DNA fragmentation during the canning process. Overall, CR and ITS1 show high potential for use in identification of canned tuna

31 products; however, further optimization of the assay may be necessary in order to improve amplification and sequencing success rates.

33

34 Keywords: DNA mini-barcoding; canned tuna; species identification; mitochondrial control region; first 35 internal transcribed spacer region 


\section{Introduction}

Fish species substitution is a type of misbranding that involves one fish species being substituted for another and sold as a mislabeled product. Mislabeling of fish species has been known to occur on the commercial market, with one U.S. market survey reporting that $33 \%$ of fish tested nationwide were mislabeled (Warner et al. 2013) and another study finding that $25 \%$ of fish samples collected in North America were potentially mislabeled (Wong and Hanner 2008). Mislabeling of fish products is carried out for reasons such as economic gain or avoidance of trade restrictions (Rasmussen and Morrissey 2008). Fish that are substituted or mislabeled are considered in violation of the Federal Food Drug and Cosmetic Act Section 403: Misbranded Food (21 U.S.C. 343). The potential for seafood mislabeling on the commercial market has become an increasing concern due to factors such as changes in the supply of particular fish species, increasing international trade, and increased production of processed seafood (Rasmussen Hellberg and Morrissey 2011). Whole, unprocessed fish can typically be identified by morphological characteristics. However, species identification becomes more challenging after commercial processing, when distinguishing external features of the fish have been removed.

Canned tuna is among the top-three consumed seafoods in the United States (NFI 2014), and has high potential to be the target of intentional or unintentional mislabeling. There are fourteen species listed in the Code of Federal Regulations (CFR) that can legally be sold in the United States as canned tuna fish (21 CFR 161.190). Canned tuna labeled as "white" can only contain albacore (Thunnus alalunga) with a Munsell value of 6.3 or higher while "light" tuna can contain any species listed in 21 CFR 161.190, as long as the tuna has a Munsell value $\geq$ 5.3. Different tuna species have varying quality, value, availability, and restrictions, leading to the potential for fraudulent species substitution (Chuang et al. 2012; Jacquet and Pauly 2008). For example, the average 2014 ex-vessel price paid in the U.S. for commercial landings of skipjack tuna (Katsuwonus pelamis) was US\$1.50/kg while the average price paid for bigeye tuna (Thunnus obesus) was US\$6.78/kg (NMFS 2015). Besides economic deception, tuna species mislabeling can also present a risk to human health. For example, sushi products labeled as "white tuna" have been reported to instead contain escolar (Lepidocybium flavorunneum) (Lowenstein et al. 2009; Warner et al. 2013). Escolar contains high levels of wax esters and is banned for sale in Japan and Italy because it can cause gastrointestinal distress (EFSA 2004). Proper labeling of canned tuna is also needed to allow at-risk consumers to properly follow the 
U.S. Food and Drug Administration (FDA)/U.S. Environmental Protection Agency (EPA) guidelines for fish consumption (FDA/EPA 2014). In order to limit mercury exposure, children and pregnant women are advised to eat no more than six ounces per week of canned albacore, but are encouraged to eat eight to twelve ounces of fish lower in mercury, such as light canned tuna.

Due to the processed nature of canned tuna, DNA-based testing is typically required for species identification (Espiñeira et al. 2009; Quinteiro et al. 1998). DNA barcoding is one of the major DNA-based tests used to identify fish species, and it has been adopted by the FDA for testing of regulatory samples (Handy et al. 2011a; Handy et al. 2011b). This method is a sequencing-based test that differentiates between animal species based on a standardized gene fragment (Hebert et al. 2003). In fish, the standard fragment used for DNA barcoding is 655 base pairs (bp) in length and is located near the 5 ' end of the cytochrome $c$ oxidase subunit 1 (COI) mitochondrial gene (Handy et al. 2011a). DNA barcoding has proven to be a highly successful method for differentiating most fish species, but the COI gene fragment cannot always successfully differentiate between closely-related tuna species due to low genetic divergences (Cawthorn et al. 2011; Ward et al. 2009). Furthermore, the high-heat treatment that occurs during the canning process degrades DNA to fragments roughly 100 to $360 \mathrm{bp}$ in length (Rasmussen and Morrissey 2009), often preventing species identification with the full-length COI barcode.

DNA mini-barcoding, which targets shorter regions within the full-length barcode, can be employed to differentiate fish species even after heavy processing (Rasmussen Hellberg and Morrissey 2011; Shokralla et al. 2015). A COI mini-barcoding system has been developed for the identification of fish species; however, canned tuna products could not consistently be differentiated at the species level with this method and the use of alternative genetic markers was suggested (Shokralla et al. 2015). Previous studies have reported some success in differentiating canned tuna using short fragments of the mitochondrial gene coding for cytochrome $b$ (Espiñeira et al. 2009; Unseld et al. 1995); however, these studies did not consider the possibility of introgression, which has been reported to occur in a small percentage of cases and results in identical or extremely similar mitochondrial DNA sequences across multiple species (Viñas and Tudela 2009). The mitochondrial DNA control region (CR), which is a non-coding stretch of DNA that shows high levels of genetic variation, is a promising option for differentiating tuna species using DNA mini-barcoding. Previous studies have reported the ability to reliably identify tuna species based on sequence variation in a fragment of 
100 the CR approximately 450 bp in length (Cawthorn et al. 2011; Viñas and Tudela 2009). This region has also

101 been studied with introgressed tuna sequences and a secondary nuclear fragment targeting the first internal

102 transcribed spacer region (ITS1; 600-650 bp) has been identified for supplemental species differentiation

103 (Chow et al. 2006; Viñas and Tudela 2009). Despite the success of these genetic markers in differentiating

104 tuna species, the fragments targeted by previous studies are too long to be reliably recovered from canned

105 tuna products. Therefore, the objective of this study was to develop a DNA mini-barcoding system for tuna

106 species identification based on the CR and ITS1 and to test this system against a variety of canned tuna

107 products.

\section{Materials and Methods}

109 Primer design and optimization

110 Primers were designed to target a short $(<250 \mathrm{bp})$ fragment of the $\mathrm{CR}$ in tuna fish species listed in the

111 CFR for canned tuna (21 CFR 161.190). A total of 1,580 CR sequences were downloaded from GenBank for

112 the following species: Atlantic bluefin tuna (Thunnus thynnus), albacore tuna (Thunnus alalunga), bigeye

113 tuna (Thunnus obesus), yellowfin tuna (Thunnus albacares), Southern bluefin tuna (Thunnus maccoyii),

114 longtail tuna (Thunnus tonggol), blackfin tuna (Thunnus atlanticus), skipjack tuna (Katsuwonus pelamis),

115 slender tuna (Allothunnus fallai), bullet tuna (Auxis rochei), frigate tuna (Auxis thazard), kawakawa

116 (Euthynnus affinis), and Pacific bluefin tuna (Thunnus orientalis). Although T. orientalis is not listed in the

117 CFR for canned tuna, it is now considered to be a separate species from T. thynnus (Collete 1999; ITIS 2015).

118 The downloaded CR sequences included introgressed individuals of T. thynnus and T. orientalis, as identified

119 in previous studies (Alvarado Bremer et al. 2005; Carlsson et al. 2007; Carlsson et al. 2004; Viñas and

120 Tudela 2009). CR sequences were not available in GenBank for two of the species listed in the CFR for

121 canned tuna: spotted tunny (Euthynnus alletteratus) and black skipjack tuna (Euthynnus lineatus). All

122 sequences were aligned with ClustalW using the default settings in MEGA 5.2 (Tamura et al. 2011). The

123 sequences were then manually examined in BioEdit Sequence Alignment Editor, v.7.1.3.0 (Hall 1999) and

124 potential primer-binding sites were identified by searching for conserved regions flanking highly variable

125 regions. Parameters such as primer-dimer potential, \%GC, and annealing temperatures were assessed using

126 the Thermo Scientific Multiple Primer Analyzer online tool

127 (http://www.thermoscientificbio.com/webtools/multipleprimer/). Based on the results of in silico analyses, a 
128 cocktail of three primers was designed for amplification of a 236-bp region of the CR (Table 1). Two reverse

129 primers were designed to account for differences in the primer-binding region among the target species.

130 Phylogenetic analysis of this genetic region was carried out in MEGA 5.2 (Tamura et al. 2011) using a subset

131 of sequences representing each target species. Genetic divergence was calculated using the Kimura 2-

132 parameter distance method (Kimura 1980) with pairwise deletion for missing data, and a neighbor-joining

133 (NJ) tree was compiled (Saitou and Nei 1987). The robustness of the tree was evaluated using nonparametric

134 bootstrap analysis with 1,000 iterations. In order to allow for differentiation of albacore-like T. thynnus and T.

135 alalunga, an additional primer set was designed to target a short $(<250 \mathrm{bp})$ region of ITS1 in both species

136 (Table 1). Primers were designed based on ITS1 sequences for T. alalunga, T. thynnus, and albacore-like T.

137 thynnus published previously (Chow et al. 2006; Viñas and Tudela 2009). Primer design and optimization, as

138 well as phylogenetic analysis, were carried out using the same methodology described above for the CR.

139 Following phylogenetic analyses, all newly designed primers were synthesized with M13 tails to facilitate

140 DNA sequencing (Handy et al. 2011a). Primers were optimized using gradient polymerase chain reaction

141 (PCR) with annealing temperatures of $45^{\circ}-65^{\circ} \mathrm{C}$ (temperature increasing in $2^{\circ} \mathrm{C}$ increments) using a

142 Mastercycler nexus gradient thermal cycler (Eppendorf, Hamburg, Germany). Additional PCR parameters

143 are described in the "PCR and sequencing" section. Optimal reaction conditions were determined based on

144 amplification success with canned $K$. pelamis (CR primers only), canned T. alalunga, and fresh/frozen $T$.

145 alalunga. Following optimization, primers were tested against commercially canned tuna samples as

146 described below.

147 Sample collection

148 A total of 53 canned tuna fish products representing a variety of commonly sold species were collected

149 for use in testing the DNA mini-barcoding system developed here (Table 2). Products were purchased from 6

150 online retail sources and 8 retail outlets in Orange County, CA. Fish tissue $(\sim 10 \mathrm{mg})$ was collected from each

151 canned tuna sample using sterile forceps and placed into a sterile $1.5 \mathrm{ml}$ microcentrifuge tube for DNA

152 extraction. The remaining portion of each sample was stored at $-80^{\circ} \mathrm{C}$.

153 DNA extraction

154 DNA extraction was carried out for all fish samples using the DNeasy Blood and Tissue Kit, Spin-

155 Column protocol (Qiagen, Valencia, CA) with modifications described previously (Handy et al. 2011a; 
156 Handy et al. 2011b). Buffer ATL $(50 \mu \mathrm{l})$ and Proteinase K (5.56 $\mu \mathrm{l})$ were added to each sample tube

157 described above and tissues were lysed at $56^{\circ} \mathrm{C}$ for $1-3 \mathrm{~h}$, with vortexing approximately every $30 \mathrm{~min}$. After

158 lysis, Buffer AL $(55.6 \mu 1)$ and 95\% ethanol $(55.6 \mu 1)$ were added and each sample was vortexed. Samples

159 were then transferred to silica spin columns, centrifuged at 8,000 rpm for $1 \mathrm{~min}$, and transferred to fresh

160 collection tubes. Wash buffer AW1 (140 $\mathrm{ll})$ was then aliquoted into each spin column and samples were

161 again centrifuged at 8,000 rpm for 1 min before being placed in a fresh collection tube. Wash buffer AW2

$162(140 \mu \mathrm{l})$ was then added to each spin column followed by a centrifugation step of 14,000 rpm for $3 \mathrm{~min}$.

163 Finally, the silica columns were placed in $1.5 \mathrm{ml}$ microcentrifuge tubes and $50 \mu 1$ of pre-heated Buffer AE

$164\left(37^{\circ} \mathrm{C}\right)$ were added to each column. Samples were incubated at room temperature for $1 \mathrm{~min}$, followed by

165 centrifugation at $8,000 \mathrm{rpm}$ for $1 \mathrm{~min}$ to allow elution of the DNA. The extracted DNA was stored at $-80^{\circ} \mathrm{C}$

166 until PCR and sequencing. Reagent blanks with no fish tissue added were included as negative controls for

167 each set of samples extracted.

168 Samples that failed sequencing underwent a repeat DNA extraction that incorporated the use of the MP

169 FastPrep-24 Tissue and Cell Homogenizer (MP Biochemicals, Solon, Ohio). One sample of fish tissue (20-25

$170 \mathrm{mg}$ ) was collected from each sample and placed into an MP Lysing Matrix A tube (MP Biochemicals).

171 Buffer ATL (180 $\mu$ l) from the DNeasy Blood and Tissue Kit was added to each Lysing Matrix A tube and the

172 tubes were homogenized in the FastPrep-24 instrument at $6.0 \mathrm{~m} / \mathrm{s}$ for $40 \mathrm{~s}$. Samples were then spun down

173 briefly and Proteinase K $(20 \mu \mathrm{l})$ was added to each sample. The tissues were lysed for $2 \mathrm{~h}$ with vortexing

174 approximately every $30 \mathrm{~min}$. After lysis, DNA extraction was carried out using the DNeasy Blood and Tissue

175 Kit according to the manufacturer's instructions. DNA was eluted in $50 \mu 1$ of preheated $\left(37^{\circ} \mathrm{C}\right) \mathrm{Buffer} \mathrm{AE}$.

176 Reagent blanks with no fish tissue added were included as negative controls for each set of samples extracted.

$177 \quad$ PCR and sequencing

178 The DNA samples extracted from each product underwent PCR along with reagent blanks and non-

179 template controls. Each reaction included the following components: 0.5 OmniMix HS PCR bead (Cepheid,

180 Sunnyvale, CA), $0.5 \mu 1$ of each $10 \mu \mathrm{M}$ primer or primer cocktail (Table 1), 2-3 $\mu 1$ DNA template, and

181 molecular grade water for a total volume of $25 \mu 1$. The CR mini-barcode region was amplified using one 10

$182 \mu \mathrm{M}$ forward primer (CR_F) and two reverse primers mixed together (CR_R1 and CR_R2, each at a

183 concentration of $10 \mu \mathrm{M}$ in the mixture), while the ITSI target was amplified with one $10 \mu \mathrm{M}$ forward primer 
184 (ITS1_F) and one $10 \mu \mathrm{M}$ reverse primer (ITS1_R). A subset of samples was initially tested with both 2 and 3

$185 \mu \mathrm{l}$ of DNA. Increased sequencing success was achieved with $3 \mu \mathrm{l}$ DNA and this volume was used in

186 subsequent testing. PCR for the CR mini-barcode region was carried out under the following conditions:

$18794^{\circ} \mathrm{C}$ for $2 \mathrm{~min} ; 35$ cycles of $94^{\circ} \mathrm{C}$ for $30 \mathrm{~s}, 49^{\circ} \mathrm{C}$ for $40 \mathrm{~s}$, and $72^{\circ} \mathrm{C}$ for $1 \mathrm{~min}$; and a final extension of $72^{\circ} \mathrm{C}$

188 for $10 \mathrm{~min}$. Thermocycling for ITS1 included the same parameters except that the annealing temperature was

189 adjusted to $61^{\circ} \mathrm{C}$. Thermocycling was carried out using a Mastercycler nexus gradient thermal cycler

190 (Eppendorf). PCR products $(10 \mu \mathrm{l})$ were loaded onto pre-cast 2.0\% E-Gel agarose gels (Life Technologies,

191 Carlsbad, CA) and the gels were run for 10 min with an E-Gel Powerbase (Life Technologies). The results

192 were photographed with a Transilluminator FBDLT-88 (Fisher Scientific, Hampton, New Jersey) and a

193 FOTO/Analyst Express (Fotodyne, Hartland, WI) and visualized with PCIMAGE (version 5.0.0.0 Fotodyne).

194 PCR products then underwent cleanup using ExoSAP-IT (Affymetrix, Santa Clara, CA) according to the

195 manufacturer's instructions. All samples and negative controls were then sent to GenScript (Piscataway, NJ)

196 for bi-directional sequencing using M13 primers (Table 1) with BigDye Terminator v3.1 Cycle Sequencing

197 Kit (Life Technologies) and a 3730xl Genetic Analyzer (Life Technologies).

198 Sequence analysis

199 Sequences were assembled and edited using Geneious R7 (Biomatters, Ltd., Auckland, New Zealand)

200 (http://www.geneious.com, Kearse et al. 2012). Consensus sequences were aligned using ClustalW with the

201 default settings in Geneious R7 and trimmed to the target CR or ITS1 fragments. The consensus sequence

202 lengths, number of ambiguities, and percent high quality bases (HQ\%) were recorded for each sample.

203 Sequences were queried in GenBank using the Basic Local Alignment Search Tool (BLAST) and the top

204 species matches were recorded. Samples that could not be identified at the species level with BLAST were

205 subjected to phylogenetic analysis using MEGA 5.2, as described above. Any sample found to be potentially

206 mislabeled was subjected to a second round of DNA extraction, PCR, and sequencing to confirm the initial

207 result.

208 Results and Discussion

209 Phylogenetic analysis

210 Phylogenetic analysis of the CR mini-barcode targeted by the primers developed in this study revealed

211 clear differentiation for ten of the thirteen tuna species for which sequences were available, with strong 
212 bootstrap support (Fig. 1). While non-introgressed sequences showed clear differentiation across all thirteen

213 species, inclusion of the introgressed sequences resulted in an inability to separate T. thynnus from $T$.

214 orientalis and an inability to differentiate albacore-like T. thynnus from T. alalunga. Although the inability

215 to differentiate introgressed individuals of T. thynnus and T. orientalis is a limitation of this methodology,

216 bluefin tuna are highly-valued and are almost exclusively prepared as a delicacy in sashimi and sushi dishes

217 (SeafoodHealthFacts 2015). Since neither of these species is typically found in canned tuna products, a

218 longer CR fragment ( $450 \mathrm{bp}$ ) previously found to differentiate these two species could be used for

219 identification of bluefin tuna in raw or lightly processed tuna products (Viñas and Tudela 2009). On the

220 other hand, T. alalunga is commonly found in canned tuna and, although most reference sequences of this

221 species grouped in a species-specific cluster (Fig. 1), one sequence grouped more closely to an albacore-like

222 T. thynnus sequence. The inability to differentiate T. alalunga and albacore-like T. thynnus has been reported

223 previously for the $\sim 450$ bp region of CR targeted by Viñas and Tudela (2009). Although introgression of

224 these two species is known to occur, it is an uncommon event, with only $2-3 \%$ of $T$. thynnus showing an

225 identical sequence to T. alalunga (Viñas and Tudela 2009). However, this could be problematic if a tuna

226 product labeled as containing T. alalunga showed a top sequence match to T. thynnus. In order to verify

227 species in this case, additional analysis would be recommended using a nuclear DNA target. In this study,

228 ITS1 was chosen as the supplemental nuclear DNA target, due to a previous study reporting the ability to

229 differentiate T. alalunga and albacore-like T. thynnus using a $\sim 650 \mathrm{bp}$ region of the ITS1 region (Viñas and

230 Tudela 2009). In order to allow for identification in a canned tuna product, primers targeting a 179-bp region

231 within ITS1 were designed in the current study. As shown in Figure 2, phylogenetic analysis of T. alalunga

232 and T. thynnus reference sequences for this region resulted in clear separation between the two species, with

233 all albacore-like $T$. thynnus sequences grouping within the $T$. thynnus cluster (100\% bootstrap support).

234 Among species groups for which more than one CR reference sequence was available, the average

235 intraspecies genetic variation for the CR mini-barcode ranged from $0.60 \pm 0.39 \%$ for T. obesus to $12.54 \pm$

$2362.32 \%$ for K. pelamis, not including introgressed sequences. Similarly, Cawthorn et al. (2011) previously

237 reported $T$. obesus to show the lowest average intraspecies variation $(0.46 \pm 0.08 \%)$ among Thunnus species

238 for a 450-bp fragment of the CR. In order for a DNA target to be used for species differentiation with DNA

239 barcoding, the maximum intraspecies variation must be less than the minimum interspecies variation. This is 
240 commonly referred to as a DNA barcode gap and can be represented graphically by plotting the maximum 241 intraspecies divergence on the $\mathrm{x}$-axis and the minimum interspecies divergence on the $\mathrm{y}$-axis (Rasmussen et 242 al. 2009). Species that have a DNA barcode gap will then be represented by data points that fall above the 1:1

243 ratio line between these axes, while species with data points falling below the line cannot be differentiated 244 with the gene target. As shown in Figure 3, a barcode gap was present for the CR mini-barcode region 245 targeted in this study for four of the seven species that could be analyzed in this manner. Due to the inclusion 246 of introgressed sequences, $T$. orientalis, T. thynnus, and T. alalunga did not have barcode gaps for the CR 247 mini-barcode region. However, when introgressed sequences were excluded, all seven species showed a CR 248 mini-barcode gap (results not shown). DNA barcode gaps could not be determined for species with only one 249 reference sequence available, as intraspecies variation could not be calculated in these cases. Use of the ITS1 250 supplementary marker to differentiate T. alalunga from albacore-like T. thynnus revealed the presence of a 251 barcode gap (Fig. 3). These results indicate that the ITS1 fragment targeted in this study could be used for 252 species confirmation in instances where a sample labeled as albacore tuna shows a top species match to $T$. 253 thynnus based on the CR mini-barcode.

\section{Sequencing results}

255 Of the 53 samples tested in this study with the CR mini-barcode, 26 showed successful PCR

256 amplification based on the results of gel electrophoresis and 24 were successfully bi-directionally sequenced

257 (Table 2). This includes 23 samples extracted initially and 1 sample labeled as "white albacore tuna" that 258 underwent a repeat DNA extraction with the MP FastPrep-24 instrument. The sequences had an average 259 consensus length of $232 \pm 14 \mathrm{bp}$, average $\mathrm{HQ} \%$ of $82.6 \pm 22.2 \%$, and an average ambiguity percentage of

$260 \quad 0.20 \pm 0.49 \%$. The quality of these sequences was slightly lower than previous species identification studies 261 involving the full-length COI barcode, which have reported averages of $87.5-93.6 \% \mathrm{HQ}$ and $0.05-0.14 \%$ 262 ambiguous bases (Kane and Hellberg 2016; Quinto et al. 2016). The difference in quality is likely due to the 263 highly processed nature of the canned tuna products, as compared to uncooked meat products examined in 264 the previous studies. Among the 24 canned tuna products for which sequences were obtained, 21 could be 265 identified at the species level based on the results of BLAST, with a query coverage of $\geq 98 \%$ and at least a $26695 \%$ identity match (Table 2). 
Two of the products that could not be identified at the species level with BLAST (T18 and T50) were labeled as either albacore or white tuna and showed $99 \%$ sequence identity to multiple GenBank entries for

269 both T. alalunga and T. thynnus. As shown in Figure 1, the CR mini-barcode sequences for these two

270 products grouped within the T. alalunga/albacore-like T. thynnus clade. In order to verify species, these two 271 canned tuna samples were subsequently sequenced with the ITS1 primers designed in this study (Table 1). A

272 successful sequence was obtained for one (T50) of the two samples and this result allowed for a positive

273 identification of T. alalunga, with 100\% sequence identity in GenBank. Furthermore, as shown in Figure 2,

274 the ITS1 sequence for this sample showed a clear phylogenetic grouping within the T. alalunga cluster.

275 The third sample that could not be identified at the species level based on the results of BLAST was 276 labeled as yellowfin tuna (T14). The CR mini-barcode for this sample showed a 99\% identity match to 277 thirteen GenBank entries for T. albacares and to one entry for T. thynnus (Accession ID DQ087565). While

278 it is possible that this represents an instance of introgression, previous studies reporting introgression

279 between these two species could not be found. The T. thynnus entry was published as part of a study that 280 sequenced T. thynnus larvae collected in the Gulf of Mexico (Carlsson et al. 2007). T. albacares is also 281 known to inhabit the Gulf of Mexico (Collette and Nauen 1983) and it is possible that this sample was 282 morphologically misidentified in its larval form. Furthermore, when the CR mini-barcode for T14 was 283 analyzed alongside the reference sequences used in this study, it showed a clear grouping within the $T$. 284 albacares clade (Fig. 1). Therefore, based on the combination of BLAST and phylogenetic results, the 285 sample was determined to be T. albacares.

286 Among the two successfully sequenced samples labeled as "tuna" or "light tuna", one was identified as $K$. 287 pelamis and the other was identified as T. alalunga, respectively. Both of these species are listed in the CFR 288 for canned tuna, so these two products are considered to be properly labeled (21 CFR 161.190). However, the 289 use of T. alalunga in a product labeled as "light tuna" could be misleading to consumers that are intentionally 290 limiting their consumption of T. alalunga due to mercury concerns, as products containing T. alalunga are 291 typically associated with the designation of "white tuna" (Burger and Gochfeld 2004).

292 One instance of mislabeling was discovered in this study, with a sample labeled as tongol tuna identified 293 as striped bonito (Sarda orientalis) with 98\% sequence identity. This result was confirmed upon re294 sequencing and the sample was determined to be mislabeled, as striped bonito is not listed in the CFR for 
295 canned tuna. In this case, it is possible that $S$. orientalis was accidentally harvested alongside tongol tuna and 296 processed into cans labeled as tongol tuna, considering that striped bonito often school with small tunas in 297 the Indian and Pacific Oceans (Collette et al. 2011). Although this specific substitution was not reported 298 previously, S. orientalis has been known to be processed as canned tuna (Lin and Hwang 2007). The rate of 299 mislabeling found in this study (4.5\%) is similar to a previous study on canned salmon, which tested 80 300 products and found 5\% to be mislabeled (Rasmussen Hellberg et al. 2011). Another study investigating 301 canned tuna products in European countries reported a higher mislabeling rate of 15\%, with mislabeling 302 found in products labeled as T. albacares, A. rochei, and A. thazard (Espiñeira et al. 2009).

303 In this study, the sequencing success rate was highest among products labeled as albacore or white tuna 304 (64.3\%), followed by products labeled as yellowfin tuna (50\%) and tongol tuna (50\%). During primer 305 optimization, amplification success was obtained with albacore tuna (canned and fresh/frozen) as well as 306 skipjack tuna (canned). However, only one of ten commercial samples labeled as skipjack tuna was 307 successfully sequenced and only one of the five products labeled as light tuna was successfully sequenced. 308 Additional optimization based on sequencing success in both fresh/frozen and canned samples may help to 309 improve the performance of the assay. Interestingly, sequencing success in the current study was observed 310 more frequently in samples containing oil (57.9\% success), including olive, canola, and soybean oil, 311 compared to samples canned in water with no oil (42.9\% success) or samples canned in water and vegetable 312 broth with no oil (18.2\% success). Similarly, Chapela et al. (2007) reported that higher quantities of DNA 313 were obtained from tuna samples canned in oil than from samples canned in vinegar, brine, or tomato sauce, 314 suggesting a protective effect of oil. Because most samples with sequencing failure also showed a negative 315 result following gel electrophoresis, there appears to have been a problem with PCR amplification of the 316 target region. Possible explanations for this include the presence of PCR inhibitors, lack of primer-binding 317 and DNA fragmentation from the canning process. Most samples that failed sequencing had short sequence 318 reads $(\sim 100 \mathrm{bp})$ that were poor quality and did not pass assembly. These reads showed a similar pattern of 319 chromatogram peaks as the first $\sim 100$ bp for the sequence reads which were successfully assembled, 320 suggesting that the primers were binding but that the target fragment was not completely elongated. Similarly, 321 previous studies have reported limited success in amplifying 200-400 bp fragments of DNA from canned 322 tuna (Lin and Hwang 2007; Quinteiro et al. 1998; Unseld et al. 1995). However, when these studies targeted 
323 shorter regions of DNA ranging from 123 to $176 \mathrm{bp}$ in length, amplification was successful, indicating that

324 DNA may be fragmented to less than 200 bp during the canning process. In the few cases where no sequence

325 reads were recovered, a possible explanation for sequencing failure could be the presence of a non-tuna

326 species that could not be amplified by the CR primers.

\section{Conclusions}

328 In the current study, a DNA mini-barcoding system was developed for the identification of fish species

329 commonly found in canned tuna. Phylogenetic analysis revealed that a 236-bp CR mini-barcode could

330 differentiate all 13 tuna species examined, except in rare cases of introgression involving T. thynnus/T.

331 alalunga and T. thynnus/T. orientalis. Use of a supplemental ITSI marker allowed for the differentiation of

332 introgressed individuals of T. alalunga and T. thynnus. Although the methodology developed in this study

333 does not allow for the differentiation of introgressed individuals of T. thynnus and T. orientalis, these species

334 are not typically found in canned tuna, and can be identified with a previously identified stretch of the CR.

335 Laboratory testing of the CR primers developed in this study demonstrated successful identification for $T$.

336 alalunga, K. pelamis, T. tonggol, and T. albacares in canned tuna, as well as S. orientalis, which is not listed

337 on the CFR for canned tuna and was detected in a mislabeled product. However, DNA sequencing was

338 unsuccessful in a number of products, likely due to factors such as DNA fragmentation and PCR inhibitors

339 present in canned tuna. Use of a shorter genetic region within the CR and/or further optimization of the assay

340 may help to improve PCR amplification and sequencing success.

341 Acknowledgements

342 We would like to thank the Chapman University Summer Undergraduate Research Fellowship (SURF)

343 Program and Chapman University Schmid College of Science and Technology for providing funding and

344 support for this project.

345 Compliance with Ethical Standards

346 Funding: This study was funded by Chapman University (no grant number available).

347 Conflict of Interest: Rosalee S. Hellberg declares that she has no conflict of interest. Jacquelyn K. Mitchell

348 declares that she has no conflict of interest.

349 Ethical approval: This article does not contain any studies with human participants or animals performed by

350 any of the authors. 
351 Informed consent: Not applicable.

352 References

353 Alvarado Bremer JR, Viñasa J, Mejutoc J, Elyd B, Plae C (2005) Comparative phylogeography of Atlantic

354 bluefin tuna and swordfish: the combined effects of vicariance, secondary contact, introgression,

355 and population expansion on the regional phylogenies of two highly migratory pelagic fishes.

$356 \quad$ Molecular Phylogenetics and Evolution 36:169-187

357 Burger J, Gochfeld M (2004) Mercury in canned tuna: white versus light and temporal variation. Environ Res $358 \quad 96: 239-249$

359 Carlsson J, McDowell JR, Carlsson JE, Graves JE (2007) Genetic identity of YOY bluefin tuna from the 360 eastern and western Atlantic spawning areas. J Hered 98:23-28

361 Carlsson J, McDowell JR, Diaz-Jaimes P, Carlsson JE, Boles SB, Gold JR, Graves JE (2004) Microsatellite

362 and mitochondrial DNA analyses of Atlantic bluefin tuna (Thunnus thynnus thynnus) population

363 structure in the Mediterranean Sea. Mol Ecol 13:3345-3356

364 Cawthorn D-M, Steinman HA, Witthuhn RC (2011) Establishment of a mitochondrial DNA sequence

365 database for the identification of fish species commercially available in South Africa. Mol Ecol

$366 \quad$ Resour 11:979-991

367 Chow S, Nakagawa T, Suzuki N, Takeyama H, Matsunaga T (2006) Phylogenetic relationships among

368 Thunnus species inferred from rDNA ITS1 sequence. J Fish Biol 68:24-35

369 Chuang P-S, Chen M-I, Shiao J-C (2012) Identification of tuna species by a real-time polymerase chain

370 reaction technique. Food Chem 133:1055-1061

371 Collete BB (1999) Mackerels, molecules, and morphology. In: Seret B, Sire J-Y (eds) Proc. 5th Indo-Pac.

372 Fish Conf., Noumea, Paris. pp 149-164

373 Collette B et al. (2011) Sarda orientalis. The IUCN Red List of Threatened Species. v. 2015.2

$374 \quad$ http://www.iucnredlist.org/details/170313/0.

375 Collette BB, Nauen CE (1983) FAO Species Catalogue. Vol. 2. Scombrids of the world. An annotated and 376 illustrated catalogue of tunas, mackerels, bonitos and related species known to date. Rome: FAO.

$377 \quad$ FAO Fish. Synop. 125(2):137 p. 
EFSA (2004) European Food Safety Authority. Opinion of the Scientific Panel on contaminants in the food chain related to the toxicity of fishery products belonging to the family of Gempylidae. EFSA Journal 92:1-5

Espiñeira M, Gonzalez-Lavin N, Vieites JM, Santaclara FJ (2009) Development of a method for the identification of scombroid and common substitute species in seafood products by FINS. Food Chem 117:698-704

FDA/EPA (2014) Fish: What Pregnant Women and Parents Should Know. http://www.fda.gov/Food/FoodbornelllnessContaminants/Metals/ucm393070.htm. Accessed $8 / 2 / 2015$

Handy SM et al. (2011a) A single laboratory validated method for the generation of DNA barcodes for the identification of fish for regulatory compliance. J AOAC 94:201-210

Handy SM et al. (2011b) Single laboratory validated method for DNA-barcoding for the species identification of fish for FDA regulatory compliance. U.S. Food and Drug Administration Standard Operating Procedure. Updated September 2011. Accessible at http://www.fda.gov/food/foodscienceresearch/dnaseafoodidentification/ucm237391.htm. Accessed $6 / 15 / 2015$.

Hebert PDN, Cywinska A, Ball SL, deWaard JR (2003) Biological identifications through DNA barcodes. P Roy Soc Lond B Bio 270:313-321

ITIS (2015) Integrated Taxonomic Information System on-line database. http://www.itis.gov. Accessed November 16, 2015

Jacquet JL, Pauly D (2008) Trade secrets: Renaming and mislabeling of seafood. Mar Policy 32:309-318

Kane DE, Hellberg RS (2016) Identification of species in ground meat products sold on the U.S. commercial market using DNA-based methods. Food Control 59:158-163

Kearse M et al. (2012) Geneious Basic: an integrated and extendable desktop software platform for the organization and analysis of sequence data. Bioinformatics 28:1647-1649

Kimura M (1980) A simple method of estimating evolutionary rate of base substitutions through comparative studies of nucleotide sequences. Journal of Molecular Evolution 16:111-120 
Lin WF, Hwang DF (2007) Application of PCR-RFLP analysis on species identification of canned tuna. Food Control 18:1050-1057

Lowenstein JH, Amato G, Kolokotronis SO (2009) The real maccoyii: identifying tuna sushi with DNA barcodes - contrasting characteristic attributes and genetic distances. PLoS ONE 4:e7866

NFI (2014) National Fisheries Institute. Top 10 Consumed Seafoods. Raw data from the National Marine Fisheries Service. https:/www.aboutseafood.com/about/about-seafood/top-10-consumed-seafoods. Accessed 11/17/2015

NMFS (2015) National Marine Fisheries Service. Fisheries of the United States, 2014. U.S. Department of

Quinteiro J et al. (1998) Use of mtDNA direct polymerase chain reaction (PCR) sequencing and PCRrestriction fragment length polymorphism methodologies in species identification of canned tuna. $\mathrm{J}$ Agric Food Chem 46:1662-1669

Quinto CA, Tinoco R, Hellberg RS (2016) DNA barcoding reveals mislabeling of game meat species on the U.S. commercial market. Food Control 59:386-392

Rasmussen Hellberg RS, Morrissey MT (2011) Advances in DNA-based techniques for the detection of seafood species substitution on the commercial market. JALA 16:308-321

Rasmussen Hellberg RS, Naaum AM, Handy SM, Hanner RH, Deeds JR, Yancy HF, Morrissey MT (2011)

Rasmussen RS, Morrissey MT (2008) DNA-based methods for the identification of commercial fish and seafood species. Compr Rev Food Sci F 7:280-295

Rasmussen RS, Morrissey MT (2009) Application of DNA-based methods to identify fish and seafood substitution on the commercial market. Compr Rev Food Sci F 8:118-154

Rasmussen RS, Morrissey MT, Hebert PDN (2009) DNA barcoding of commercially important salmon and

431 Saitou N, Nei M (1987) The neighbor-joining method: a new method for reconstructing phylogenetic trees. 
SeafoodHealthFacts (2015) Seafood Health Facts: Making Smart Choices. Canned Tuna. http://seafoodhealthfacts.org/seafood_choices/canned_tuna.php. Accessed 11/16/15

Shokralla S, Hellberg RS, Handy SM, King I, Hajibabaei M (2015) A DNA mini-barcoding system for authentication of processed fish products. Scientific Reports 5:e15894

Tamura K, Peterson D, Peterson N, Stecher G, Nei M, Kumar S (2011) MEGA5: Molecular evolutionary genetics analysis using maximum likelihood, evolutionary distance, and maximum parsimony methods. Mol Biol Evol 28:2731-2739

Unseld M, Beyermann B, Brandt P, Hiesel R (1995) Identification of the species origin of highly processed meat products by mitochondrial DNA sequences. PCR Methods and Applications 4:241-243

Viñas J, Tudela S (2009) A validated methodology for genetic identification of tuna species (Genus Thunnus).

Ward RD, Hanner R, Hebert PDN (2009) The campaign to DNA barcode all fishes, FISH-BOL. J Fish Biol $74: 329-356$

Warner K, Timme W, Lowell B, Hirshfield M (2013) Oceana study reveals seafood fraud nationwide. Washington, DC: Oceana. 
461

462

463

464

465 
Table 1. Primers used in this study. All primers include M13 tails described previously (Handy et al. 2011a).

\begin{tabular}{|c|c|c|c|c|c|}
\hline $\begin{array}{l}\text { Primer } \\
\text { set }\end{array}$ & Primer name & Primer sequence (5'-3') & Described & Ta & $\begin{array}{l}\text { Target fragment } \\
\text { length }^{\mathrm{a}}\end{array}$ \\
\hline \multirow[t]{3}{*}{$\mathrm{CR}$} & Tuna CR_F & $\begin{array}{l}\text { CAC GAC GTT GTA AAA CGA CGC AYG TAC ATA } \\
\text { TAT GTA AYT ACA CC }\end{array}$ & In this work & $49^{\circ} \mathrm{C}$ & $236 \mathrm{bp}$ \\
\hline & Tuna CR_R1 & $\begin{array}{l}\text { GGA TAA CAA TTT CAC ACA GGC TGG TTG GTR } \\
\text { GKC TCT TAC TRC A }\end{array}$ & In this work & & \\
\hline & Tuna CR_R2 & $\begin{array}{l}\text { GGA TAA CAA TTT CAC ACA GGC TGG ATG GTA } \\
\text { GGY TCT TAC TGC G }\end{array}$ & In this work & & \\
\hline \multirow[t]{2}{*}{ ITS1 } & ITS1_F & $\begin{array}{l}\text { CAC GAC GTT GTA AAA CGA CTC TCC TGG TCA } \\
\text { GGA CCT CGT }\end{array}$ & In this work & $61^{\circ} \mathrm{C}$ & $179 \mathrm{bp}$ \\
\hline & ITS1_R & $\begin{array}{l}\text { GGA TAA CAA TTT CAC ACA GGA AGC CTC CGC } \\
\text { TKC CGC GCT T }\end{array}$ & In this work & & \\
\hline \multirow[t]{2}{*}{ M13 } & M13F (-29) & CAC GAC GTT GTA AAA CGA C & $\begin{array}{l}\text { Handy et al. } \\
\text { (2011a) }\end{array}$ & $\mathrm{N} / \mathrm{A}$ & $\mathrm{N} / \mathrm{A}$ \\
\hline & M13R & GGA TAA CAA TTT CAC ACA GG & $\begin{array}{l}\text { Handy et al. } \\
\text { (2011a) }\end{array}$ & $\mathrm{N} / \mathrm{A}$ & $\mathrm{N} / \mathrm{A}$ \\
\hline
\end{tabular}

467

${ }^{a}$ Not including primers

468

469 
470 Table 2. Summary of the 53 canned tuna products analyzed in this study with the CR mini-barcode. Top species matches were determined using BLAST.

\begin{tabular}{lllll}
\hline Product label & n & Expected species & Top species match in GenBank & \% Sequence \\
& & & & identity \\
\hline Albacore/white tuna & 7 & T. alalunga & T. alalunga & $97-99 \%$ \\
Albacore/white tuna & 2 & T. alalunga & T. alalunga/T. thynnus & $99 \%$ \\
Albacore/white tuna & 5 & T. alalunga & Failed sequencing & N/A \\
Light tuna & 1 & Variety of potential species & T. alalunga & $95 \%$ \\
Light tuna & 4 & Variety of potential species & Failed sequencing & N/A \\
Skipjack tuna & 1 & K. pelamis & K. pelamis & $97 \%$ \\
Skipjack tuna & 9 & K. pelamis & Failed sequencing & N/A \\
Tongol tuna & 2 & T. tonggol & T. tonggol & $97-98 \%$ \\
Tongol tuna & 1 & T. tonggol & S. orientalis & $98 \%$ \\
Tongol tuna & 3 & T. tonggol & Failed sequencing & N/A \\
Tuna & 1 & Variety of potential species & K. pelamis & $97 \%$ \\
Tuna & 3 & Variety of potential species & Failed sequencing & N/A \\
Yellowfin tuna & 8 & T. albacares & T. albacares & $99-100 \%$ \\
Yellowfin tuna & 1 & T. albacares & T. albacares/T. thynnus & $99 \%$ \\
Yellowfin tuna & 5 & T. albacares & Failed sequencing & N/A \\
\hline & & & &
\end{tabular}

${ }^{a}$ Mislabeled sample. 


\section{Figure Captions}

474 Figure. 1 Neighbor-joining tree of the 236-bp CR mini-barcode targeted in this study. GenBank accession

475 numbers are shown for all reference sequences. The Kimura 2-parameter method was used to calculate

476 genetic distances and bootstrap values greater than $70 \%$ are shown. The tree includes three of the canned

477 commercial samples tested in the current study (T14, T18, T50)

478 Figure. 2. Neighbor-joining tree of the 179-bp ITS1 fragment targeted in this study. GenBank accession

479 numbers are shown for all reference sequences and Katsuwonus pelamis was used as an outgroup. The

480 Kimura 2-parameter method was used to calculate genetic distances and bootstrap values greater than 70\%

481 are shown. The tree includes one of the canned commercial samples tested in the current study (T50)

482 Figure. 3 Mini-barcode gaps for the tuna species targeted in this study, including introgressed sequences.

483 Data points are representative of the CR mini-barcode unless otherwise noted. Genetic distance was

484 calculated using the Kimura 2-parameter method. Species with only one reference sequence are not shown 


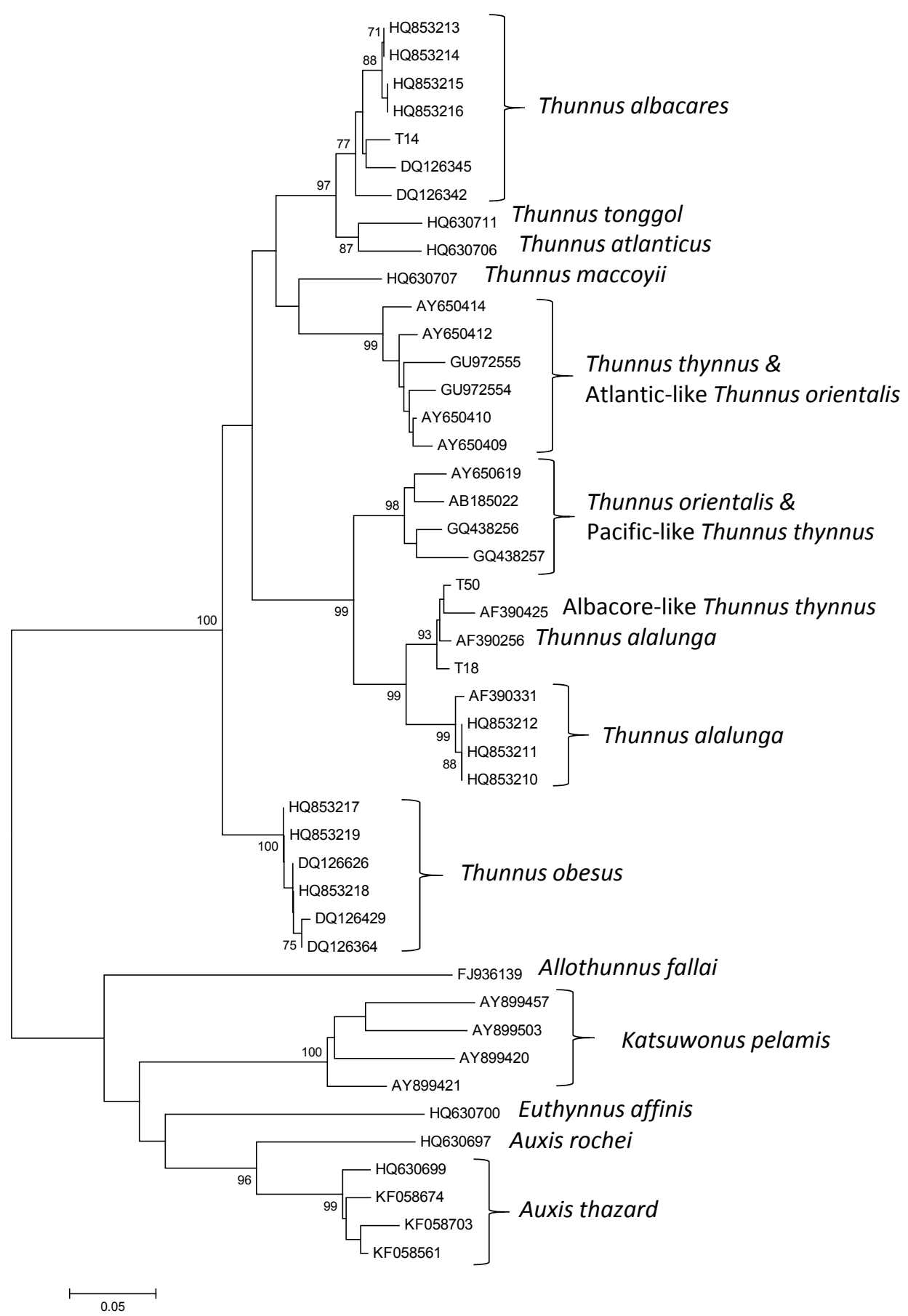




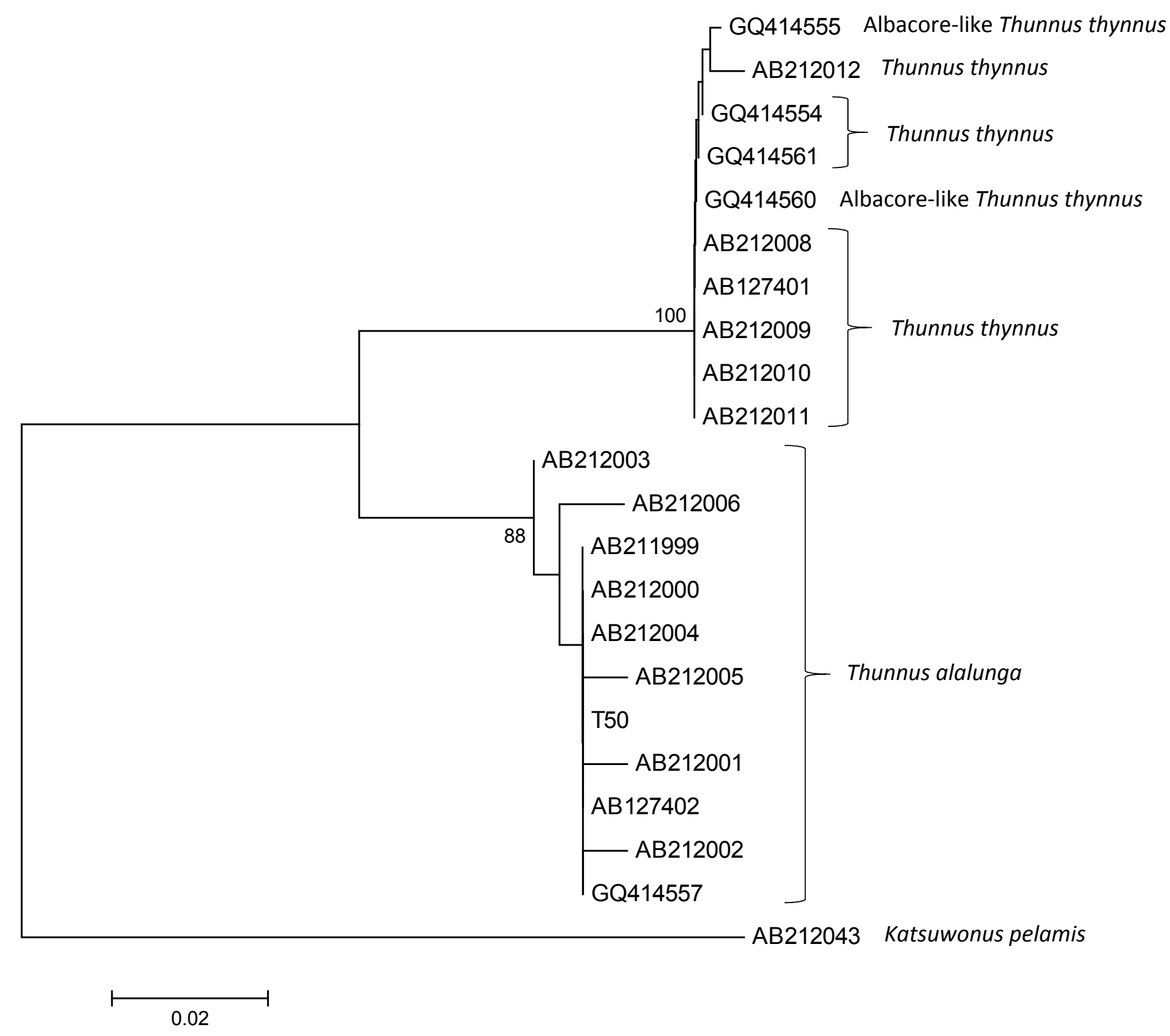




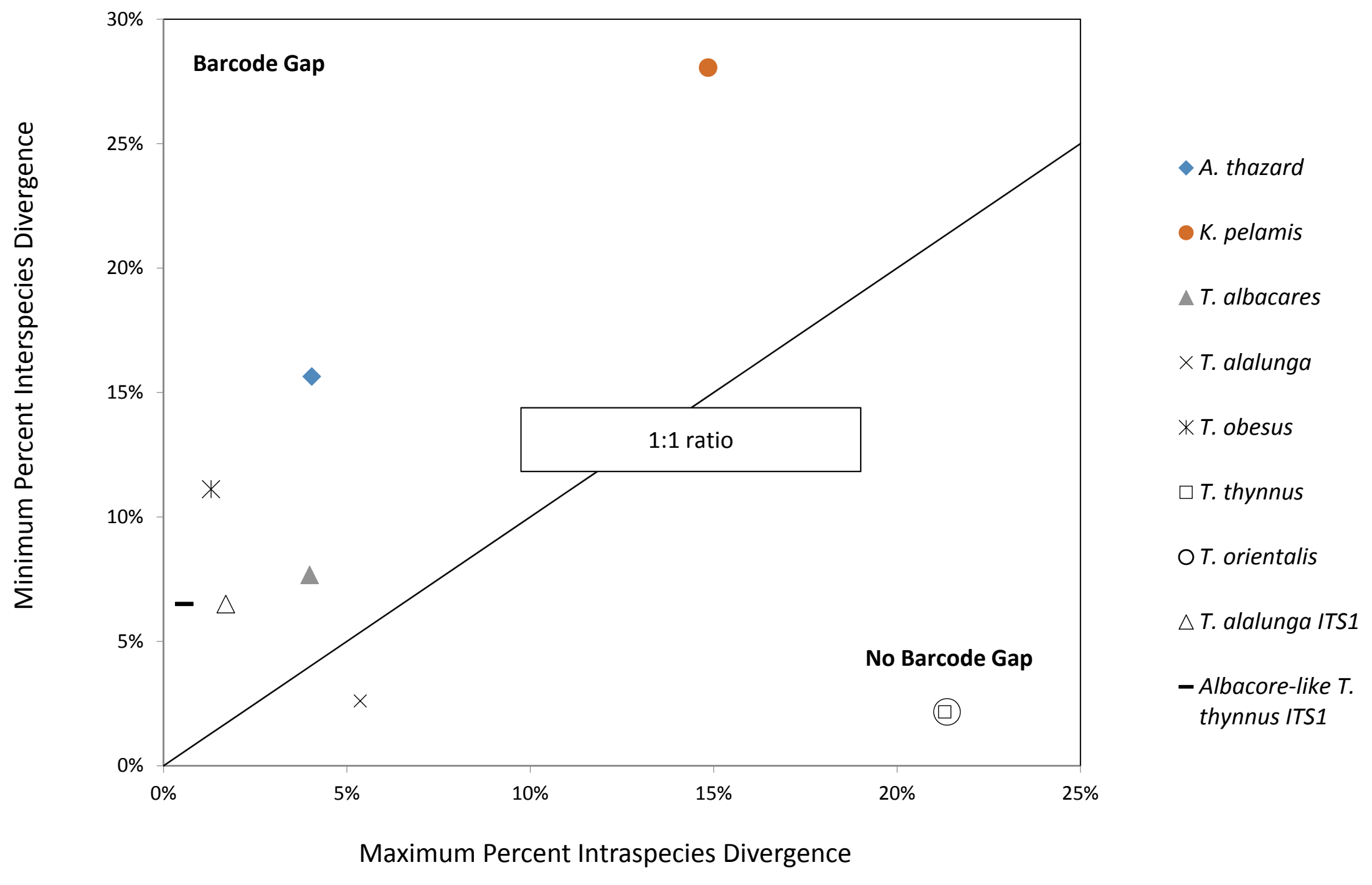

